\title{
Wpływ zdolności absorpcyjnej przedsiębiorstwa na jego elastyczność strategiczną: wyniki badań empirycznych
}

Dr Monika Stelmaszczyk iD

Uniwersytet Jana Kochanowskiego w Kielcach, Katedra Zarządzania

\section{Wprowadzenie do problematyki oddziatywania zdolności absorpcyjnej na elastyczność strategiczną}

Jeżeli zasoby przedsiębiorstwa są wartościowe, rzadkie, niepowtarzalne i nie mają substytutów, mogą zapewnić temu przedsiębiorstwu przewagę konkurencyjną ${ }^{1}$. Jednym $\mathrm{z}$ takich zasobów jest zdolność przedsiębiorstwa do tworzenia nowej wiedzy oraz swobodnego jej wykorzystywania. Dlatego zdolność absorpcyjna, będąca zestawem zdolności opartych na wiedzy² ${ }^{2}$ może być źródłem przewagi konkurencyj$n^{2}{ }^{3}$. Pionierzy i prekursorzy koncepcji zdolności absorpcyjnej - Cohen i Levinthal ${ }^{4}$ - w publikacji traktowanej jako klasyk literatury przedmiotu wskazali na możliwość wyjaśniania przewagi konkurencyjnej za pomocą zdolności absorpcyjnej. Dwadzieścia lat później Volberda, Foss i Lyles 5 przeprowadzili analizę bibliometryczną dotychczasowych rozważań teoretycznych oraz dokonań empirycznych w badanym obszarze. W zaproponowanym modelu wśród wyników zdolności absorpcyjnej na pierwszym miejscu również wymienili przewagę konkurencyjną.

1 J. Barney, Firm resources and sustained competitive advantage, „Journal of Management” 1991, no. 17(1), s. 99-120.

2 Potencjalna zdolność absorpcyjna (nabycie i asymilacja wiedzy zewnętrznej) oraz faktyczna zdolność absorpcyjna (transformacja i eksploatacja wiedzy pochodzącej ze źródeł zewnętrznych).

3 H.W. Volberda, N.J. Foss, M.A. Lyles, Absorbing the concept of absorptive capacity: How to realize its potential in the organization field, „Organization Science” 2010, vol. 21(4), s. 931-951.

4 M.W. Cohen, D.A. Levinthal, Absorptive capacity: A new perspective on learning and innovation, „Administrative Science Quarterly” 1990, vol. 35(1), s. 128-152.

5 H.W. Volberda, N.J. Foss, M.A. Lyles, Absorbing the concept of absorptive capacity..., s. 944. 
Tymczasem już Barney ${ }^{6}$ wśród najważniejszych komponentów przewagi konkurencyjnej wskazał elastyczność strategiczną, która jest zdolnością przedsiębiorstwa do reagowania i dostosowywania się do zmian zachodzących w otoczeniu. Z kolei Zahra i George ${ }^{7}$ zaznaczyli w swojej teoretyczno-koncepcyjnej publikacji, zajmującej trzecie miejsce $\mathrm{w}$ rankingu najczęściej cytowanych prac na temat zdolności absorpcyjnej $^{8}$, że zdolność ta może prowadzić do osiągnięcia oraz utrzymania elastyczności strategicznej. Do podobnych wniosków doszli Todorova i Durisin ${ }^{9}$. Skoncentrowali się oni jednak na rozważaniach teoretycznych, nie dokonując ich weryfikacji empirycznej. Z kolei Matthyssens, Pauwels i Vandenbempt ${ }^{10}$ podjęli próbę identyfikacji barier rozwoju zdolności absorpcyjnej. Pozwoliło to, ich zdaniem, lepiej zrozumieć, jak organizacje biznesowe mogą pozostać elastyczne na wymagających i szybko zmieniających się rynkach. Autorzy zaprezentowali pogląd, że budowanie elastyczności strategicznej wymaga rozwoju zdolności absorpcyjnej. Jednak nie zbadali wpływu tej zdolności na elastyczność strategiczną. Po prostu założyli, że on istnieje, nie udowadniając tej tezy. Zidentyfikowali jedynie bariery zdolności absorpcyjnej, uznając tym samym, że przyczyniają się one do pogłębiania tzw. sztywności strategicznej (strategic rigidity). Dopiero w kierunkach przyszłych badań wskazali potrzebę przetestowania hipotezy mówiącej o występowaniu zależności pomiędzy tymi zmiennymi.

Dokonując analizy publikacji indeksowanych w bazach Scopus oraz Web of Science, jednych z największych międzynarodowych i elektronicznych naukowych baz danych, znaleziono niewiele artykułów podejmujących tę problematykę. W pierwszym etapie po wpisaniu słów kluczowych absorptive capacity i strategic fexibility wyłoniono 23 publikacje w pierwszej bazie i $77 \mathrm{w}$ drugiej. Następnie nałożone zostały kolejne warunki ograniczające, tj. nauki społeczne, publikacje recenzowane, dostępne w pełnej wersji tekstowej. W kolejnym etapie usunięto dublujące się publikacje. W ten sposób otrzymano listę zaledwie dziewięciu prac, które poddano analizie treści. Okazało się, że sześć z nich nie wnosi żadnego istotnego wkładu w zagadnienie oddziaływania zdolności absorpcyjnej na elastyczność strategiczną.

6 J. Barney, Firm resources...

7 S.A. Zahra, G. George, Absorptive capacity: A review, reconceptualization, and extention, „Academy of Management Review" 2002, vol. 27(2), s. 185-203.

8 A. Lis, Rozwój badań naukowych w zakresie zdolności absorpcyjnej organizacji, „Organizacja i Kierowanie" 2018, nr 3(182), s. 77-96; M. Stelmaszczyk, Konceptualizacja zdolności absorpcyjnej, [w:] I. Krawczyk-Sokołowska (red.), Zrównoważony rozwój w zarzq̨dzaniu i finansach, Wydawnictwo Politechniki Częstochowskiej, Częstochowa 2019, s. 86-93.

9 G. Todorova, B. Durisin, Absorptive capacity: Valuing a reconceptualization, „Academy of Management Review" 2007, vol. 32(3), s. 774-786.

10 P. Matthyssens, P. Pauwels, K. Vandenbempt, Strategic flexibility, rigidity and barriers to the development of absorptive capacity in business markets: Themes and research perspectives, „Industrial Marketing Management” 2005, vol. 34(6), s. 547-554. 
Pozostały zatem trzy artykuły ${ }^{11}$. Ich analiza doprowadziła do następujących wniosków. Dotychczasowy stan wiedzy na temat wpływu zdolności absorpcyjnej na elastyczność strategiczną jest niewielki. Uzasadnienie podjęcia badań w tym zakresie jest ściśle związane z zapotrzebowaniem na wiedzę w tym obszarze.

Celem rozdziału jest zatem wzbogacenie rozważań na temat koncepcji zdolności absorpcyjnej o jej wpływ na elastyczność strategiczną przedsiębiorstwa.

\section{Hipotezy badawcze}

Zdolność absorpcyjna (absorptive capacity) jest zdolnością przedsiębiorstwa do uznania wartości wiedzy znajdującej się w jego otoczeniu, przyswojenia jej i wykorzystania w praktyce. W niniejszych rozważaniach przyjmuje się, że zdolność absorpcyjna jest konstruktem wielowymiarowym, na który składają się nabycie i asymilacja wiedzy zewnętrznej (potencjalna zdolność absorpcyjna) oraz jej transformacja i eksploatacja (faktyczna zdolność absorpcyjna) ${ }^{12}$. Przy tym nabycie wiedzy zewnętrznej polega na jej rozpoznaniu i wejściu w posiadanie, asymilacja to inaczej jej przyswojenie, transformacja sprowadza się do połączenia wiedzy bazowej z nowo nabytą wiedzą zewnętrzną, natomiast eksploatację należy rozumieć jako wykorzystanie jej w praktyce ${ }^{13}$.

Nawiązując do teoretycznych rozważań Zahry i George'a14 oraz kontynuując podjęty przez nich wątek, stwierdzić należy, że potencjalna zdolność absorpcyjna przedsiębiorstwa (potential absorptive capacity) odgrywa bardzo ważną rolę w odnawianiu jego bazy wiedzy, jak również w kreowaniu umiejętności niezbędnych

11 W pierwszym z nich zaproponowano model teoretyczny łączący oparte na wiedzy kompetencje firm e-usługowych, takie jak kapitał ludzki, kapitat strukturalny oraz zdolność absorpcyjną, z ich zdolnościami konkurencyjnymi, czyli jakością usług, dostaw, elastycznością i kosztami - P. Oliveira, A.V. Roth, W. Gilland, Achieving competitive capabilities in e-services, „Technological Forecasting and Social Change” 2002, vol. 69(7), s. 721-739. W drugim potwierdzono empirycznie tezę o tym, że elastyczność strategiczna wzmacnia wpływ zdolności technologicznej (będącej źródtem zdolności absorpcyjnej) na innowacje eksploracyjne - K.Z. Zhou, F. Wu, Technological capability, strategic flexibility, and product innovation, „Strategic Management Journal” 2010, vol. 31(5), s. 547-561. Z kolei w trzeciej pracy wykazano mediacyjny wpływ zdolności absorpcyjnej na zależności pomiędzy wymiarami elastyczności łańcucha dostaw a wydajnością sklepów detalicznych - R. Obayi i wsp., Improving retail supply flexibility using buyer-supplier relational capabilities, „International Journal of Operations \& Production Management” 2017, vol. 37(3), s. 343-362.

12 S.A. Zahra, G. George, Absorptive capacity..., s. 185-203.

13 M. Stelmaszczyk, S. Jopkiewicz, Efekty mediacyjne w kontekście nabywania i eksploatacji wiedzy zewnętrznej czynnikiem sukcesu w rozwoju organizacji, „Przegląd Organizacji” 2019, nr 4, s. 51-58.

14 S.A. Zahra, G. George, Absorptive capacity..., s. 196. 
do konkurowania na zmieniających się rynkach. Przedsiębiorstwa, które charakteryzują się elastycznością w wykorzystywaniu swoich zasobów, mogą zmieniać konfigurację tych zasobów, w wyniku czego wykorzystują pojawiające się okazje strategiczne. Okazje te mogą przyczynić się do osiągnięcia doskonałej wydajności z powodu przewagi pierwszego gracza na rynku, szybkości reakcji czy też osiągnięcia innych korzyści strategicznych. Potencjalna zdolność absorpcyjna może zatem oddziaływać na elastyczność strategiczną przedsiębiorstwa. To znaczy, że przedsiębiorstwa $\mathrm{z}$ dobrze rozwiniętymi zdolnościami rozpoznania, nabycia i asymilacji wiedzy pochodzącej ze źródeł zewnętrznych (potencjalna zdolność absorpcyjna) mogą mieć większe szanse na osiągnięcie przewagi konkurencyjnej dzięki większej elastyczności strategicznej, tj. elastyczności w rekonfigurowaniu baz zasobów, przesuwaniu ich w zależności od potrzeb oraz umiejętności wykorzystywania ich do alternatywnych zastosowań (elastyczność zasobów i elastyczność ich koordynacji). W związku z tym sformułowano następujące hipotezy:

H1: Istnieje pozytywna zależność pomiędzy potencjalną zdolnością absorpcyjną a elastycznością zasobów.

H2: Istnieje pozytywna zależność pomiędzy potencjalną zdolnością absorpcyjną a elastycznością koordynacji.

W niniejszych rozważaniach elastyczność strategiczna (strategic fexibility) zdefiniowana została jako zdolność przedsiębiorstwa do realokacji i rekonfiguracji zasobów oraz procesów organizacyjnych w celu szybkiego reagowania i odpowiadania na zmiany zachodzące w dynamicznym otoczeniu ${ }^{15}$. Powołując się na koncepcję zaproponowaną przez Sancheza ${ }^{16}$, elastyczność strategiczna powstaje w wyniku rozwijania organizacyjnej elastyczności koordynacji w pozyskiwaniu i wykorzystywaniu elastycznych zasobów. Na elastyczność strategiczną składają się zatem elastyczność zasobów (resource flexibility) oraz elastyczność koordynacji (coordination flexibility).

Elastyczność zasobu jest cechą tego zasobu. O elastyczności zasobu decydują jego właściwości techniczne w następujących obszarach:

- zakres alternatywnych zastosowań danego zasobu (elastyczność zasobów zwiększa się wraz ze wzrostem wariantów ich wykorzystania);

- koszt i trudność alternatywnego zastosowania zasobu (niski koszt oraz łatwość przechodzenia z jednego zastosowania zasobu na inny oznaczają jego wyższą elastyczność);

- czas wymagany do przejścia na alternatywne wykorzystanie zasobu.

15 R. Sanchez, Strategic flexibility in product competition, „Strategic Management Journal” 1995, vol. 16(S1), s. 135-159; R. Sanchez, Preparing for an uncertain future. Managing organizations for strategic flexibility, „International Studies of Management and Organization” 1997, vol. 27(2), s. 71-94; K.Z. Zhou, F. Wu, Technological capability...

16 R. Sanchez, Strategic flexibility... 
Z kolei elastyczność koordynacji jest cechą organizacji. Określana jest poprzez:

- definiowanie nowych zastosowań zasobów organizacji (np. decyzja na temat produktów, które przedsiębiorstwo zaprojektuje, wyprodukuje i/lub wprowadzi na rynek);

- tworzenie nowych kombinacji zasobów (konfigurowanie portfela zasobów) do określonego zastosowania, który jest przedmiotem zainteresowania organizacji;

- wdrażanie dostępnych zasobów za pomocą systemów i procesów organizacyjnych.

Ponadto każdy z aspektów elastyczności koordynacji zależy od zakresu, kosztów, trudności i czasu alternatywnego zastosowania zasobów. Na przykład elastyczność koordynacji w zakresie definiowania nowych zastosowań posiadanych zasobów zwiększa się wraz ze wzrostem zakresu wykorzystania dostępnych zasobów oraz w wyniku obniżki kosztów czy zmniejszenia trudności oraz czasu niezbędnego do zdefiniowania zastosowań tych zasobów ${ }^{17}$.

Jeżeli zgodnie z wcześniejszymi rozważaniami założymy, że potencjalna zdolność absorpcyjna oddziałuje na elastyczność zasobów i elastyczność koordynacji, warta wyjaśnienia wydaje się kwestia, dlaczego ta prawidłowość zachodzi. Potencjalna zdolność absorpcyjna sprowadza się do umiejętności nabycia (wejścia w posiadanie) oraz asymilacji (analizy i zrozumienia) wartościowej wiedzy zewnętrznej. Jednak nabycie i zrozumienie wiedzy o kluczowym znaczeniu dla funkcjonowania przedsiębiorstwa stanowi dopiero połowę sukcesu. Samo nabycie wiedzy nie gwarantuje, że zasób ten zostanie wykorzystany. Nowa wiedza powinna więc zostać połączona z posiadaną przez przedsiębiorstwo wiedzą bazową, a następnie osadzona w pamięci i strukturze organizacyjnej ${ }^{18}$. Te działania, zgodnie z procesowym ujęciem zdolności absorpcyjnej autorstwa Zahry i George'a ${ }^{19}$, noszą nazwę faktycznej zdolności absorpcyjnej (realized absorptive capacity). Autorka sugeruje więc, że im bardziej organizacja zaangażuje się w faktyczną zdolność absorpcyjną (transformację i eksploatację wiedzy zewnętrznej), tym więcej wartościowej wiedzy nabytej z zewnątrz wykorzysta do podwyższania swojej elastyczności w zakresie zasobów i koordynacji. Innymi słowy, proponuje, żeby potencjalnej zdolności absorpcyjnej przypisać rolę mediatora. Zaproponowała więc następujące hipotezy:

$\mathrm{H}_{3}$ : Faktyczna zdolność absorpcyjna jest mediatorem zależności pomiędzy potencjalną zdolnością absorpcyjną a elastycznością zasobów.

$\mathrm{H}_{4}$ : Faktyczna zdolność absorpcyjna jest mediatorem zależności pomiędzy potencjalną zdolnością absorpcyjną a elastycznością koordynacji.

17 R. Sanchez, Preparing for an uncertain future..., s. 73-75.

18 N. Pangarkar, The formula for successful innovation at SAS: Integrating internal and external knowledge, „Global Business \& Organizational Excellence” 2018, vol. 37(2), s. 24-31.

19 S.A. Zahra, G. George, Absorptive capacity... 


\section{Wyniki badań empirycznych}

\section{Metodyka badań}

Obiektem badań jest przedsiębiorstwo Vive Textile Recycling Sp. z o.o., zajmujące się pozyskiwaniem, sortowaniem i przetwarzaniem odzieży używanej. Jest liderem branży recyklingu tekstyliów w Polsce, a także największym w kraju importerem odzieży używanej. Odzież jest segregowana przy zastosowaniu nowoczesnych, w pełni skomputeryzowanych linii do sortowania. Produkty, porządkowane według 700 grup asortymentowych, eksportowane są do ponad 80 krajów (Europa Zachodnia, Wspólnota Niepodległych Państw, Azja, Afryka). Dostarczane są również do sieci 33 sklepów z odzieżą używaną, usytuowanych na terenie Polski, których właścicielem jest Vive Textile Recycling.

Badanie zostało przeprowadzone na przełomie maja i czerwca 2019 roku. Do pomiaru zależności pomiędzy zdolnością absorpcyjną a elastycznością strategiczną wykorzystano kwestionariusz ankiety. W badaniu zastosowano siedmiopunktową skalę Likerta, począwszy od 1 - „zdecydowanie nie” do 7 - „zdecydowanie tak". Kwestionariusz został skierowany do osób pełniących funkcje kierownicze, tj. do 138 respondentów. Uzyskano 78 ważnych obserwacji i taką ich liczbę przyjęto do analiz. Wskaźnik poziomu realizacji próby (response rate) wyniósł 57\%.

Na potrzeby badań empirycznych wyodrębniono następujące rodzaje zmiennych: zmienną niezależną (potencjalna zdolność absorpcyjna), zmienne zależne (dwuwymiarowa elastyczność strategiczna: elastyczność zasobów, elastyczność koordynacji) oraz mediator, czyli zmienną pośredniczącą (faktyczna zdolność absorpcyjna).

Zmienna zależna. Potencjalna zdolność absorpcyjna zdefiniowana została jako zdolność przedsiębiorstwa do nabywania i asymilacji wiedzy zewnętrznej ${ }^{20}$. Zmierzono ją za pomocą siedmioitemowej skali opracowanej przez Flatten, Engelena, Zahrę i Brettela ${ }^{21}$. Wartość alfa Cronbacha dla tej zmiennej wyniosła 0,70.

Zmienne niezależne. Elastyczność strategiczną zdefiniowano jako zdolność przedsiębiorstwa do realokacji i rekonfiguracji zasobów oraz procesów organizacyjnych w celu szybkiego reagowania i odpowiadania na zmiany zachodzące w dynamicznym otoczeniu ${ }^{22}$. Składają się na nią dwa wymiary: elastyczność zasobów

20 Tamże.

21 T. C. Flatten, A. Engelen, S.A. Zahra, M. Brettel, A measure of absorptive capacity: Scale development and validation, „European Management Journal” 2011, vol. 29(2), s. 98-116.

22 R. Sanchez, Strategic flexibility...; R. Sanchez, Preparing for an uncertain future...; K.Z. Zhou, F. Wu, Technological capability... 
i elastyczność koordynacji, do których pomiaru wykorzystano skalę zaproponowaną przez Sancheza ${ }^{23}$ oraz zastosowaną jako miarę elastyczności strategicznej przez Zhou i $\mathrm{Wu}^{24}$ oraz innych badaczy. Wartości alfa Cronbacha dla elastyczności zasobów i elastyczność koordynacji wyniosły kolejno 0,85 i 0,93.

Mediator. Faktyczna zdolność absorpcyjna to zdolność do transformacji i eksploatacji wiedzy pochodzącej ze źródeł zewnętrznych ${ }^{25}$. Zmierzona została przy wykorzystaniu siedmioitemowej skali autorstwa Flatten, Engelena, Zahry i Brettela ${ }^{26}$. Wartość alfa Cronbacha dla tej zmiennej wyniosła 0,87.

W celu przetestowania hipotez badawczych wykonane zostały analizy statystyczne w programie Amos. W pierwszej kolejności przeprowadzono analizę podstawowych statystyk opisowych z testem normalności rozkładu Shapiro-Wilka. Następnie, wykorzystując modelowanie równań strukturalnych (structural equation modeling) metodą największej wiarygodności, zmierzono i przetestowano zależności przyczynowo-skutkowe pomiędzy potencjalną i faktyczną zdolnością absorpcyjną a elastycznością zasobów i elastycznością koordynacji. W ostatnim etapie sprawdzono istotność efektów pośrednich (mediacyjnych) faktycznej zdolności absorpcyjnej metodą bootstrapingu. Na potrzeby interpretacji przeprowadzonych analiz przyjęto, że poziom istotności a wynosi 0,05.

\section{Podstawowe statystyki opisowe mierzonych zmiennych ilościowych}

Analizę rozpoczęto od wyliczenia podstawowych statystyk opisowych. Przeprowadzono także test normalności rozkładu Shapiro-Wilka uwzględnionych w modelu zmiennych mierzonych na skali ilościowej. Okazało się, że dwie zmienne - elastyczność zasobów oraz transformacja - mają rozkład zbliżony do normalnego. Rozkłady pozostałych zmiennych są lekko odchylone od rozkładu normalnego. Wartość skośności tych zmiennych jednak nie przekroczyła progu 0,8, co oznacza, że odchylenie nie jest znaczące, a rozkład poszczególnych zmiennych jest stosunkowo symetryczny względem średniej27. Wyniki zaprezentowano w tabeli 1.

23 R. Sanchez, Strategic flexibility...; R. Sanchez, Preparing for an uncertain future...

24 K.Z. Zhou, F. Wu, Technological capability...

25 S.A. Zahra, G. George, Absorptive capacity...

26 T. C. Flatten i wsp., A measure of absorptive capacity...

27 D. George, M. Mallery, SPSS for Windows step by step: A simple guide and reference, Pearson, Boston 2010. 
Tabela 1. Podstawowe statystyki opisowe oraz wynik testu normalności rozkładu

\begin{tabular}{|l|c|c|c|r|r|r|r|c|c|}
\cline { 2 - 10 } \multicolumn{1}{c|}{} & $M$ & \multicolumn{1}{c|}{ Me } & \multicolumn{1}{c|}{$S D$} & \multicolumn{1}{c|}{ Sk. } & \multicolumn{1}{c|}{ Kurt. } & \multicolumn{1}{c|}{ Min. } & Maks. & W & $p$ \\
\hline PZA & 35,85 & 37,00 & 5,92 & $-0,80$ & 0,88 & 18,00 & 46,00 & 0,95 & 0,002 \\
\hline FZA & 36,49 & 38,00 & 6,46 & $-0,48$ & $-0,42$ & 21,00 & 49,00 & 0,97 & 0,035 \\
\hline Transformacja & 19,90 & 20,00 & 4,20 & $-0,52$ & 0,06 & 9,00 & 28,00 & 0,97 & 0,060 \\
\hline Eksploatacja & 16,59 & 17,00 & 2,97 & $-0,16$ & $-1,04$ & 10,00 & 21,00 & 0,95 & 0,003 \\
\hline EZ & 24,12 & 24,00 & 5,02 & $-0,38$ & 0,40 & 11,00 & 35,00 & 0,97 & 0,107 \\
\hline EC & 21,26 & 21,00 & 4,17 & $-0,37$ & 0,02 & 10,00 & 28,00 & 0,96 & 0,014 \\
\hline
\end{tabular}

M - średnia; Me - mediana; SD - odchylenie standardowe; Sk. - skośność; Kurt. - kurioza; Min.

- najniższa wartość rozkładu; Maks. - najwyższa wartość rozkładu; $W$ - wynik testu Shapiro-

Wilka; $p$ - poziom istotności. PZA - potencjalna zdolność absorpcyjna, FZA - faktyczna

zdolność absorpcyjna, EZ - elastyczność zasobów, EK - elastyczność koordynacji.

Źródło: opracowanie własne.

\section{Modelowanie równań strukturalnych (SEM)}

W następnej części analiz postanowiono przetestować hipotezy $\mathrm{H}_{1}$ i $\mathrm{H}_{2}$, zakładające występowanie bezpośredniego wpływu potencjalnej zdolności absorpcyjnej na każdy z dwóch wymiarów elastyczności strategicznej, oraz $\mathrm{H}_{3} \mathrm{i} \mathrm{H}_{4}$ - mówiące o mediacyjnej roli faktycznej zdolności absorpcyjnej.

W modelowaniu strukturalnym uwzględniono jedną zmienną latentną (ukrytą, nieobserwowalną) niemierzalną bezpośrednio, tj. faktyczną zdolność absorpcyjną, składającą się z dwóch wymiarów: transformacji i eksploatacji. Pozostałe zmienne są zmiennymi kontrolnymi (jawnymi, obserwowanymi) bezpośrednio mierzalnymi. Wartość testu chi ${ }^{2}\left[\chi^{2}(2)=0,007 ; p=0,996\right]$ oraz pozostałe wskaźniki (CMIN/ $\mathrm{DF}=0,004 ; \mathrm{CFI}=1,000 ; \mathrm{GFI}=1,000 ; \mathrm{RMSEA}<0,001 ; \mathrm{SRMR}=0,001)$ oznaczają dobre dopasowanie modelu do danych.

Analiza efektów bezpośrednich wykazała istotny statystycznie wpływ potencjalnej zdolności absorpcyjnej zarówno na elastyczność zasobów ( $b=0,47 ; \beta=0,55$; $p=0,001)$, jak i elastyczność koordynacji ( $b=0,49 ; \beta=0,70 ; p<0,001)$. Obie zależności są dodatnie, co oznacza, że wraz ze wzrostem potencjalnej zdolności absorpcyjnej wzrasta poziom elastyczności zasobów oraz elastyczności koordynacji. W poddanym analizie modelu uwzględniono także faktyczną zdolność absorpcyjną, jako element pośredniczący (mediujący) w zależność pomiędzy potencjalną zdolnością absorpcyjną a każdym z wymiarów elastyczności strategicznej. Na rysunku 1 zaprezentowano standaryzowane współczynniki regresji dla analizowanego modelu.

Wyniki modelowania równań strukturalnych, które zostały przedstawione na rysunku 1 i w tabeli 2, świadczą o występowaniu istotnego i dodatniego wpływu potencjalnej zdolności absorpcyjnej na faktyczną zdolność absorpcyjną. Ponadto 
faktyczna zdolność absorpcyjna istotnie i dodatnio wpływa na elastyczność zasobów i elastyczność koordynacji. Po dodaniu do modelu mediatora nieistotny okazał się wpływ potencjalnej zdolności absorpcyjnej zarówno na elastyczność zasobów, jak i na elastyczność koordynacji. Oznacza to, że mamy do czynienia $\mathrm{z}$ mediacją całkowitą.

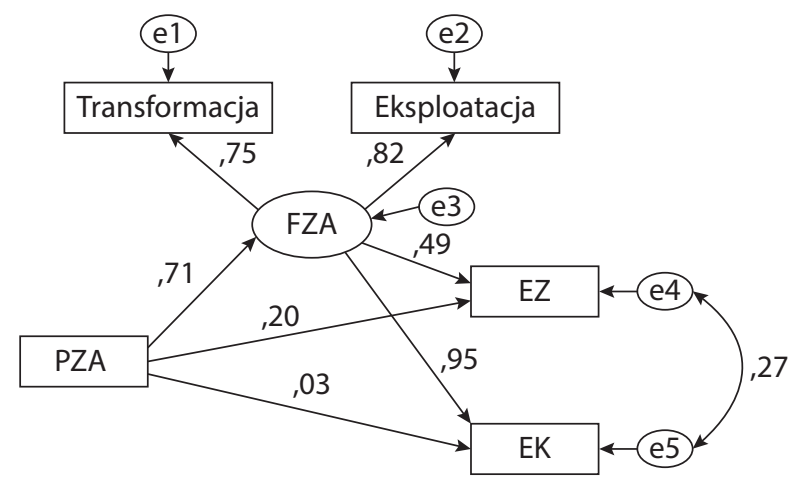

PZA - potencjalna zdolność absorpcyjna, FZA - faktyczna zdolność absorpcyjna, EZ - elastyczność zasobów, EK - elastyczność koordynacji.

Rysunek 1. Standaryzowane współczynniki wielowymiarowej analizy regresji dla efektu mediacyjnego

Źródto: opracowanie własne.

Tabela 2. Współczynniki regresji dla analizowanego modelu

\begin{tabular}{|l|l|l|c|c|c|c|c|}
\cline { 3 - 7 } \multicolumn{2}{l|}{} & $b$ & $S E$ & $\beta$ & $C R$ & $p$ \\
\hline PZA & $\rightarrow$ & FZA & 0,38 & 0,06 & 0,71 & 6,05 & $<0,001$ \\
\hline FZA & $\rightarrow$ & Transformacja & 1,00 & & 0,75 & & \\
\hline FZA & $\rightarrow$ & Eksploatacja & 0,78 & 0,10 & 0,82 & 7,52 & $<0,001$ \\
\hline FZA & $\rightarrow$ & EZ & 0,79 & 0,29 & 0,49 & 2,73 & 0,006 \\
\hline PZA & $\rightarrow$ & EZ & 0,17 & 0,13 & 0,20 & 1,27 & 0,204 \\
\hline PZA & $\rightarrow$ & EC & 0,02 & 0,10 & 0,03 & 0,19 & 0,849 \\
\hline FZA & $\rightarrow$ & EC & 1,27 & 0,25 & 0,95 & 5,15 & $<0,001$ \\
\hline
\end{tabular}

$b$ - niestandaryzowany wspótczynnik regresji, SE - błąd standardowy; $\beta$ - standaryzowany współczynnik regresji; $C R$ - critical ratio; $p$ - poziom istotności.

Źródto: opracowanie własne.

Dzięki przetestowanemu modelowi strukturalnemu zweryfikowano empirycznie hipotezy badawcze. Chcąc sprawdzić, czy efekty pośrednie (mediacyjne) są rzeczywiście istotne, przeprowadzono dodatkową analizę statystyczną metodą bootstrapingu dla próbkowania 5000. Określono w ten sposób 95-procentowe centylowe przedziały ufności. Szczegółowa analiza wyników wykazała, że oba efekty pośrednie są statystycznie istotne (tabela 3). 
Tabela 3. Analiza efektów pośrednich (mediacyjnych) faktycznej zdolności absorpcyjnej

\begin{tabular}{|l|c|c|c|c|}
\cline { 2 - 5 } \multicolumn{1}{c|}{} & $b$ & BootSE & BootLL & BootCl \\
\hline EZ & 0,298 & 0,12 & 0,149 & 0,561 \\
\hline EC & 0,475 & 0,12 & 0,315 & 0,733 \\
\hline
\end{tabular}

b - niestandaryzowany współczynnik regresji, BootSE - błąd standardowy; BootLL i BootUL - dolna i górna granica przedziału ufności.

Źródło: opracowanie własne.

Reasumując, rezultaty przeprowadzonych analiz nie dają podstaw do odrzucenia hipotez $\mathrm{H}_{1}, \mathrm{H}_{2}, \mathrm{H}_{3} \mathrm{i}$ H. Innymi słowy, można je uznać za pozytywnie przetestowane.

\section{Podsumowanie}

\section{Implikacje teoretyczne i praktyczne}

Jednym z ograniczeń spowalniających rozwój badań nad koncepcją zdolności absorpcyjnej, które zidentyfikowali Song i współautorzy 28 jako rezultat systematycznego przeglądu literatury oraz konsolidacji wyników dotychczasowych badań, jest brak przejrzystości w kwestii wpływu tej kategorii zdolności na wyniki przedsiębiorstw. Zdaniem Portera ${ }^{29}$ kreatorem wyników przedsiębiorstwa jest przewaga konkurencyjna, którą Barney ${ }^{30}$ postrzega między innymi przez pryzmat elastyczności strategicznej. Implikacją teoretyczną analiz zaprezentowanych w niniejszym rozdziale jest zatem poszerzenie wiedzy na temat oddziaływania zdolności absorpcyjnej na elastyczność strategiczną, a dokładniej wykazanie bezpośredniego wpływu potencjalnej zdolności absorpcyjnej oraz pośredniego wpływu faktycznej zdolności absorpcyjnej na elastyczność zasobów i elastyczność koordynacji.

Implikacji praktycznych jest niewątpliwie kilka. Po pierwsze, naczelne kierownictwo Vive Textile Recycling powinno pamiętać o konieczności nabywania i wykorzystywania w praktyce wartościowej wiedzy zewnętrznej, ponieważ mało która organizacja ma takie zasoby wiedzy, których potrzebuje. Po drugie, faktyczna zdolność absorpcyjna badanego przedsiębiorstwa (tj. wewnętrzna umiejętność łączenia dotychczasowej wiedzy z nowo nabytą i przyswojoną wiedzą zewnętrzną oraz

28 Y. Song, D.R. Gnyawali, M.K. Srivastava, E. Asgari, In search of precision in absorptive capacity research: A synthesis of the literature and consolidation of findings, „, Journal of Management" 2018, vol. 44(6), s. 2343-2374.

29 M.E. Porter, Przewaga konkurencyjna. Osiaganie i utrzymywanie lepszych wyników, Wydawnictwo Helion, Gliwice 2006, s. 23.

30 J. Barney, Firm resources... 
jej osadzenie w pamięci i strukturze organizacyjnej) jest niezbędna do tego, żeby nabyta i przyswojona wiedza zewnętrzna wywołała wzrost elastyczności zasobów i koordynacji. Po trzecie, zdolność absorpcyjna Vive Textile Recycling może być ważnym źródłem elastyczności strategicznej, jeżeli stworzy warunki do łatwiejszego reagowania na zmiany zachodzące w otoczeniu. Nastąpi to poprzez szybkie tworzenie nowych odmian produktów (usług) na podstawie łączenia nowej i/lub dotychczasowej wiedzy. W związku z tym relacje pomiędzy potencjalną a faktyczną zdolnością absorpcyjną mogą umożliwić lub zahamować wykorzystywanie nowej wiedzy, która jest niezbędna badanemu przedsiębiorstwu do zachowania elastycznych zasobów oraz elastycznej koordynacji tych zasobów.

Utrzymanie elastyczności strategicznej jest jednym z najważniejszych, ale i najtrudniejszych zadań menedżerów. W Vive Textile Recycling powinni oni identyfikować zmiany zachodzące na rynku, a w odpowiedzi na nie szybko przydzielać zasoby do nowych kierunków działania, przesuwać je w zależności od potrzeb oraz wykorzystywać do alternatywnych zastosowań. Rozpoznawanie potrzeb i podejmowanie działań we właściwym czasie może również wymagać zatrzymania lub cofnięcia zobowiązań dotyczących zasobów, do czego menedżerowie powinni być przygotowani.

Przeprowadzone analizy pozwolą menedżerom Vive Textile Recycling lepiej zrozumieć, jak ich przedsiębiorstwo może pozostać elastyczne na wymagających i szybko zmieniających się rynkach. Potencjalna zdolność absorpcyjna może aktywować elastyczność strategiczną, jednak nastąpi to dużo wolniej. Dopiero z udziałem faktycznej zdolności absorpcyjnej zdobędzie potencjał do przezwyciężania tzw. sztywności strategicznej (jeżeli się ona pojawi), jak również do szybszego reagowania na zmiany zachodzące w otoczeniu.

\section{Kierunki przyszłych badań}

Badania empiryczne przeprowadzone zostały w Vive Textile Recycling, przedsiębiorstwie, które zajmuje główną pozycję na rynku w sektorze przetwarzania surowców wtórnych. Dąży ono do rozwijania swojej działalności w obszarze innowacyjnych metod recyklingu, optymalizacji ponoszonych kosztów, logistyki i transportu. W przypadku każdej z podejmowanych aktywności niezbędna jest wiedza przedsiębiorstwa, jak również nowa wiedza - pochodzące ze źródeł zewnętrznych. Zdolność do jej absorbowania odgrywa zatem istotną rolę w funkcjonowaniu Vive Textile Recycling. Kierunkiem przyszłych badań powinno być więc poszukiwanie istotnych czynników, które mogłyby kształtować zdolność absorpcyjną przedsiębiorstwa. Interesującym obszarem badawczym wydają się dynamiczne zdolności, jakimi dysponują menedżerowie, ich wewnętrzna motywacja czy wykorzystywane przez nich systemy informacyjne. 
Bibliografia

Barney J., Firm resources and sustained competitive advantage, „Journal of Management” 1991, no. $17(1)$, s. $99-120$.

Cohen W.M., Levinthal D.A., Absorptive capacity: A new perspective on learning and innovation, „Administrative Science Quarterly” 1990, vol. 35(1), s. 128-152.

Flatten T. C., Engelen A., Zahra S.A., Brettel M., A measure of absorptive capacity: Scale development and validation, „European Management Journal” 2011, vol. 29(2), s. 98-116.

George D., Mallery M., SPSS for Windows step by step: A simple guide and reference, Pearson, Boston 2010.

Lis A., Rozwój badań naukowych w zakresie zdolności absorpcyjnej organizacji, „Organizacja i Kierowanie" 2018, $\mathrm{nr}$ 3(182), s. 77-96.

Matthyssens P., Pauwels P., Vandenbempt K., Strategic flexibility, rigidity and barriers to the development of absorptive capacity in business markets: Themes and research perspectives, „Industrial Marketing Management” 2005, vol. 34(6), s. 547-554.

Obayi R., Koh S. C., Oglethorpe D., Ebrahimi S. M., Improving retail supply flexibility using buyer-supplier relational capabilities, „International Journal of Operations \& Production Management" 2017, vol. 37(3), s. 343-362.

Oliveira P., Roth A.V., Gilland W., Achieving competitive capabilities in e-services, „Technological Forecasting and Social Change" 2002, vol. 69(7), s. 721-739.

Pangarkar N., The formula for successful innovation at SAS: Integrating internal and external knowledge, „Global Business \& Organizational Excellence” 2018, vol. 37(2), s. 24-31.

Porter M.E., Przewaga konkurencyjna. Osiąganie i utrzymywanie lepszych wyników, Wydawnictwo Helion, Gliwice 2006.

Sanchez R., Preparing for an uncertain future. Managing organizations for strategic flexibility, „International Studies of Management and Organization" 1997, vol. 27(2), s. 71-94.

Sanchez R., Strategic flexibility in product competition, „Strategic Management Journal” 1995, vol. 16(S1), s. 135-159.

Song Y., Gnyawali D.R., Srivastava M.K., Asgari E., In search of precision in absorptive capacity research: A synthesis of the literature and consolidation of findings, „Journal of Management” 2018, vol. 44(6), s. 2343-2374.

Stelmaszczyk M., Konceptualizacja zdolności absorpcyjnej, [w:] I. Krawczyk-Sokołowska (red.), Zrównoważony rozwój w zarządzaniu i finansach, Wydawnictwo Politechniki Częstochowskiej, Częstochowa 2019, s. 87-95.

Stelmaszczyk M., Jopkiewicz S., Efekty mediacyjne w kontekście nabywania i eksploatacji wiedzy zewnętrznej czynnikiem sukcesu w rozwoju organizacji, „Przegląd Organizacji” 2019, nr 4, s. 51-58.

Todorova G., Durisin B., Absorptive capacity: Valuing a reconceptualization, „Academy of Management Review" 2007, vol. 32(3), s. 774-786.

Volberda H.W., Foss N.J., Lyles M.A., Absorbing the concept of absorptive capacity: How to realize its potential in the organization field, „Organization Science” 2010, vol. 21(4), s. 931-951.

Zahra S.A., George G., Absorptive capacity: A review, reconceptualization, and extention, „Academy of Management Review" 2002, vol. 27(2), s. 185-203.

Zhou K.Z., Wu F., Technological capability, strategic flexibility, and product innovation, „Strategic Management Journal” 2010, vol. 31(5), s. 547-561. 


\section{Streszczenie}

Celem opracowania jest wzbogacenie rozważań na temat koncepcji zdolności absorpcyjnej o jej wpływ na elastyczność strategiczną przedsiębiorstwa. Elastyczność strategiczna opisana została za pomocą dwóch wymiarów: elastyczności zasobów oraz elastyczności koordynacji. Badanie ankietowe przeprowadzone zostało w przedsiębiorstwie Vive Textile Recycling na próbie 78 menedżerów. Do przetestowania hipotez wykorzystano modelowanie równań strukturalnych (SEM) metodą największej wiarygodności. Wartością dodaną niniejszych badań jest wykazanie bezpośredniego wpływu potencjalnej zdolności absorpcyjnej na elastyczność zasobów oraz elastyczność koordynacji, jak również mediacyjnej roli faktycznej zdolności absorpcyjnej pomiędzy potencjalną zdolnością absorpcyjną a poszczególnymi wymiarami elastyczności strategicznej badanego przedsiębiorstwa.

Słowa kluczowe: zdolność absorpcyjna, elastyczność strategiczna, mediacja

Impact of absorptive capacity of an enterprise on its strategic flexibility:
empirical results

\section{Abstract}

The aim of this paper is to enrich consideration on the concept of absorptive capacity with its impact on the strategic flexibility of an enterprise. Strategic flexibility has been described in two dimensions: resource flexibility and coordination flexibility. The survey was conducted at Vive Textile Recycling using a sample of 78 managers. Structural equation modeling (SEM) using the maximum likelihood method was used to test the hypotheses. The added value of this research is that it demonstrates the direct impact of potential absorptive capacity on resource flexibility and coordination flexibility. In addition, the mediating role of relative absorptive capacity in the relationships between the potential absorptive capacity and two dimensions of the strategic flexibility of the examined enterprise.

Keywords: absorptive capacity, strategic flexibility, mediation 